\title{
PENICILLIN BLOOD LEVELS AFTER INJECTION OF SOLID AND SEMI-FLUID OILY SUSPENSIONS OF PENICILLIN
}

\author{
BY \\ J. UNGAR \\ Research Division, Glaxo Laboratories, Ltd., Greenford, Middlesex \\ (RECEIVED FOR PUblication, MAY 14, 1948)
}

The object of injecting an oily suspension instead of an aqueous solution of penicillin is to secure delayed absorption from the depot in the muscle and to achieve a prolongation of effective penicillin blood levels from a single injection. Many vehicles have been recommended, but so far a suspension of penicillin in beeswax and arachis oil, as used by Romansky and Rittman (1944), has proved the most satisfactory. In a previous communication (J. Ungar, 1946), I have shown that the degree of prolongation of penicillin action depends, apart from individual variations in the absorptive capacity of experimental animals or patients, to a large extent on the consistency of the material (which is determined by the viscosity of the oil and by the amount of beeswax) and on the amount of penicillin in the suspension.

In a number of experiments performed since then we have repeatedly confirmed that the delayed absorption of penicillin is governed by the consistency of the final preparation; see, for example, Table I.

We have tried arachis oil, " alcoholized" arachis oil,* ethyl oleate, and cocoa butter and found that arachis oil is the most suitable medium for the suspension. We tried altering the concentration of beeswax from the original recommended by Romansky. We used suspensions of penicillin in oil containing $1,2,3,4$, and 6 per cent of beeswax, and we found that the amount of beeswax present in the final preparation is an essential factor in determining the absorption of penicillin (Tables I and II). Lowering the amount of beeswax to between 1 and 2 per cent results in a more fluid product with the obvious advantage of easier manipulation, but the blood levels after injection of these products are less satisfactory.

The technique of injecting the different preparations was constant, and possible variations of volume and temperature of the injected suspensions were rigorously controlled in all experiments.

* A mixture of ethyl esters of the total fatty acids of arachis oil.
The penicillin-oil-beeswax (P.O.B.) prepared according to the original method of Romansky has disadvantages from the point of view of administration, for it is solid at normal temperatures and has to be heated to about $50^{\circ} \mathrm{C}$. before it can be injected. Anyone who has to administer the preparation knows how cumbersome it is to fill the syringe with the heated P.O.B. and inject it quickly before it solidifies. For this reason methods have been suggested to increase the fluidity of the preparation, not by decreasing the content of beeswax, but by one of the special means used for preparation of colloids.

\section{Milled Penicillin and Beeswax}

A product of this kind is a suspension of penicillin in oil and beeswax made by passing the mixture through a special colloid mill. This milled preparation, containing 4.5 per cent of beeswax, is semi-solid at room temperature ; when heated to body temperature it can be easily drawn into a syringe and injected. Table $I$ and the Figure show blood levels in rabbits injected with the solid

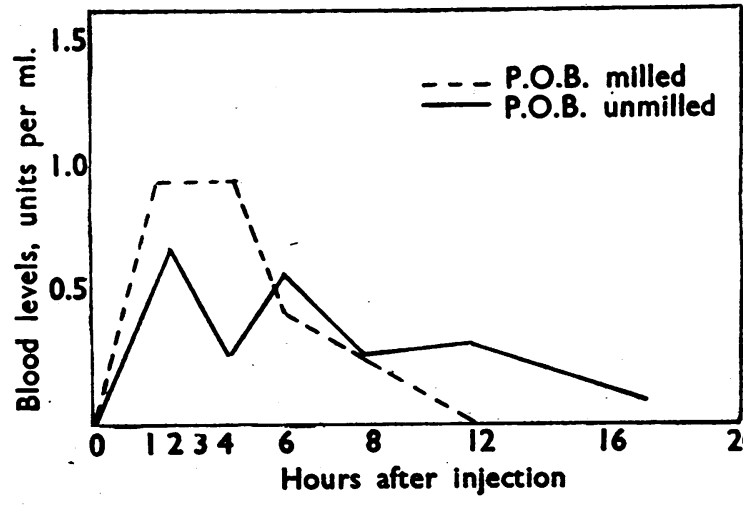

FIG.-Comparison of penicillin-oil-beeswax, milled and usual unmilled at room temperature $(142,000$ units per $\mathrm{ml}$.) (20,000 units injected in $900 \mathrm{~g}$. rabbits). 
TABLE I

BLOOD LEVELS IN RABBITS AFTER INTRAMUSCULAR INJECTION OF 50,000 UNITS OF PENICILLIN IN OIL-BEESWAX UNMIILED SUSPENSIONS

\begin{tabular}{|c|c|c|c|c|c|c|c|c|c|c|c|c|}
\hline \multirow{2}{*}{ Penicillin } & \multirow{2}{*}{$\begin{array}{c}\% \\
\text { Beeswax }\end{array}$} & \multirow{2}{*}{$\begin{array}{c}\text { Rabbit } \\
\text { no. }\end{array}$} & \multicolumn{10}{|c|}{ Hours after injection } \\
\hline & & & 2 & 4 & 6 & 8 & 10 & 12 & 14 & 16 & 18 & 20 \\
\hline \multirow[t]{4}{*}{ Crystalline sodium } & Nil & $\begin{array}{l}1 \\
2\end{array}$ & $\begin{array}{l}2.0 \\
2.0\end{array}$ & $\begin{array}{l}\mathbf{0} \\
\mathbf{0}\end{array}$ & $\begin{array}{l}\mathbf{0} \\
\mathbf{0}\end{array}$ & $\begin{array}{l}\mathbf{0} \\
\mathbf{0}\end{array}$ & $\begin{array}{l}\mathbf{0} \\
\mathbf{0}\end{array}$ & $\begin{array}{l}\mathbf{0} \\
\mathbf{0}\end{array}$ & $\begin{array}{l}\mathbf{0} \\
\mathbf{0}\end{array}$ & $\begin{array}{l}\mathbf{0} \\
\mathbf{0}\end{array}$ & $\begin{array}{l}0 \\
0\end{array}$ & $\begin{array}{l}\mathbf{0} \\
\mathbf{0}\end{array}$ \\
\hline & 1 & $\begin{array}{l}3 \\
4\end{array}$ & $\begin{array}{l}2.0 \\
2.0\end{array}$ & $\begin{array}{l}0 \\
0.03\end{array}$ & $\begin{array}{l}0 \\
0\end{array}$ & $\begin{array}{l}0 \\
0\end{array}$ & $\begin{array}{l}0 \\
0\end{array}$ & $\begin{array}{l}0 \\
0\end{array}$ & $\begin{array}{l}\mathbf{0} \\
\mathbf{0}\end{array}$ & $\begin{array}{l}\mathbf{0} \\
\mathbf{0}\end{array}$ & $\begin{array}{l}0 \\
0\end{array}$ & $\begin{array}{l}\mathbf{0} \\
0\end{array}$ \\
\hline & 2 & $\begin{array}{l}5 \\
6\end{array}$ & $\begin{array}{l}2.0 \\
2.0\end{array}$ & $\begin{array}{l}2.0 \\
2.0\end{array}$ & $\begin{array}{l}1.0 \\
1.0\end{array}$ & $\begin{array}{l}0.5 \\
0.4\end{array}$ & $\begin{array}{l}0.3 \\
0.1\end{array}$ & $\begin{array}{l}0.6 \\
0\end{array}$ & $\begin{array}{l}0 \\
0\end{array}$ & $\begin{array}{l}0 \\
0\end{array}$ & $\begin{array}{l}\mathbf{0} \\
\mathbf{0}\end{array}$ & $\begin{array}{l}0 \\
0\end{array}$ \\
\hline & 4 & $\begin{array}{l}7 \\
8\end{array}$ & $\begin{array}{l}1.5 \\
2.0\end{array}$ & $\begin{array}{l}2.0 \\
2.0\end{array}$ & $\begin{array}{l}2.0 \\
1.0\end{array}$ & $\begin{array}{l}1.0 \\
0.5\end{array}$ & $\begin{array}{l}0.25 \\
0.3\end{array}$ & $\begin{array}{l}0.06 \\
0.12\end{array}$ & $\begin{array}{l}0.12 \\
0.12\end{array}$ & $\begin{array}{l}0.1 \\
0.03\end{array}$ & $\begin{array}{l}0.03 \\
0\end{array}$ & $\begin{array}{l}0 \\
0\end{array}$ \\
\hline \multirow[t]{4}{*}{ Amorphous calcium } & Nil & $\begin{array}{r}9 \\
10\end{array}$ & 二 & $\overline{-}$ & $\overline{-}$ & 二 & $\begin{array}{l}\mathbf{0} \\
\mathbf{0}\end{array}$ & $\begin{array}{l}0 . \\
0\end{array}$ & $\begin{array}{l}\mathbf{0} \\
\mathbf{0}\end{array}$ & $\begin{array}{l}\mathbf{0} \\
\mathbf{0}\end{array}$ & $\begin{array}{l}\mathbf{0} \\
\mathbf{0}\end{array}$ & - \\
\hline & 1 & $\begin{array}{l}11 \\
12\end{array}$ & - & - & - & $=$ & $\begin{array}{l}0 \\
0\end{array}$ & $\begin{array}{l}\mathbf{0} \\
\mathbf{0}\end{array}$ & $\begin{array}{l}0 \\
0\end{array}$ & $\begin{array}{l}\mathbf{0} \\
\mathbf{0}\end{array}$ & $\begin{array}{l}0 \\
0\end{array}$ & 二 \\
\hline & 2 & $\begin{array}{l}13 \\
14\end{array}$ & 二 & 二 & - & 二 & $\begin{array}{l}0.03 \\
0.12\end{array}$ & $\begin{array}{l}0.03 \\
0.03\end{array}$ & $\begin{array}{l}\mathbf{0} \\
\mathbf{0}\end{array}$ & $\begin{array}{l}0 \\
0\end{array}$ & $\begin{array}{l}0 \\
0\end{array}$ & 二 \\
\hline & 4 & $\begin{array}{l}15 \\
16\end{array}$ & - & - & - & - & $\begin{array}{l}0.25 \\
0.25\end{array}$ & $\begin{array}{l}0.25 \\
0.1\end{array}$ & $\begin{array}{l}0.03 \\
0.1\end{array}$ & $\begin{array}{l}0 \\
0.06\end{array}$ & $\begin{array}{l}0 \\
0\end{array}$ & 二 \\
\hline
\end{tabular}

and semi-solid preparations, both containing the same amount and type of penicillin and 4.5 per cent of beeswax.

We see from Table III that with this preparation we sacrifice part of the prolonged activity. Instead of a period of from sixteen to twenty hours during which penicillin is circulating in the blood after an injection of solid P.O.B., as reported previously (Ungar, 1946), we get, after the injection of a milled suspension, detectable blood levels up to a period of twelve to fourteen hours, which is satisfactory when treatment is given twice in twenty- four hours. In Table IV are given the blood levels of patients injected intramuscularly with $1 \mathrm{ml}$. of a milled suspension of penicillin containing 300,000 units, from which it can be seen that a level of up to 0.1 unit per ml. is maintained during a period up to six hours and a level of 0.06 unit per ml. up to eleven hours.

\section{Discussion}

Penicillin suspensions in oil and beeswax prepared by simple mixing of the components are at ordinary temperatures solid and difficult to

TABLE II

BLOOD LEVELS IN RABBITS AFTER INTRAMUSCULAR INJECTION OF 30,000 UNITS IN 0.1 ML. OF UNMILLED SUSPENSION

\begin{tabular}{|c|c|c|c|c|c|c|c|c|c|c|}
\hline \multirow{2}{*}{ Sample } & \multirow{2}{*}{ Penicillin } & \multirow{2}{*}{$\begin{array}{c}\% \\
\text { Beeswax }\end{array}$} & \multirow{2}{*}{$\begin{array}{c}\text { Rabbit } \\
\text { no. }\end{array}$} & \multicolumn{7}{|c|}{ Hours after injection } \\
\hline & & & & 1 & 3 & 5 & 7 & 8 & 12 & 24 \\
\hline \multirow{2}{*}{$\left.\begin{array}{l}\operatorname{EPC} 10 / 54 \\
\operatorname{EPC} 10 / 55\end{array}\right\}$} & \multirow{2}{*}{$\begin{array}{l}\text { Crystalline } \\
\text { sodium }\end{array}$} & 1 & $\begin{array}{l}17 \\
18\end{array}$ & $\begin{array}{l}4.0 \\
4.0\end{array}$ & $\begin{array}{l}0.03 \\
0.06\end{array}$ & $\begin{array}{l}\mathbf{0} \\
\mathbf{0}\end{array}$ & $\begin{array}{l}\mathbf{0} \\
\mathbf{0}\end{array}$ & $\begin{array}{l}\mathbf{0} \\
\mathbf{0}\end{array}$ & E & $=$ \\
\hline & & 4 & $\begin{array}{l}19 \\
20\end{array}$ & $\begin{array}{l}4.0 \\
4.0\end{array}$ & $\begin{array}{l}1.0 \\
1.0\end{array}$ & $\begin{array}{l}0.5 \\
0.25\end{array}$ & $\begin{array}{l}0.2 \\
0.03\end{array}$ & $\begin{array}{l}0.06 \\
0.03\end{array}$ & $\begin{array}{l}\mathbf{0} \\
\mathbf{0}\end{array}$ & $\begin{array}{l}\mathbf{0} \\
0\end{array}$ \\
\hline \multirow{2}{*}{$\left.\begin{array}{l}\text { EPC } 10 / 56 \\
\text { EPC 10/57 }\end{array}\right\}$} & \multirow{2}{*}{$\begin{array}{l}\text { Amorphous } \\
\text { calcium }\end{array}$} & 1 & $\begin{array}{l}21 \\
22\end{array}$ & $\begin{array}{l}4.0 \\
4.0\end{array}$ & $\begin{array}{l}0.5 \\
0.12\end{array}$ & $\begin{array}{l}0.1 \\
0.03\end{array}$ & $\begin{array}{l}0.03 \\
0\end{array}$ & $\begin{array}{l}\mathbf{0} \\
\mathbf{0}\end{array}$ & $\begin{array}{l}\mathbf{0} \\
\mathbf{0}\end{array}$ & $\begin{array}{l}0 \\
0\end{array}$ \\
\hline & & 4 & $\begin{array}{l}23 \\
24\end{array}$ & $\begin{array}{l}4.0 \\
4.0\end{array}$ & $\begin{array}{l}1.5 \\
1.5\end{array}$ & $\begin{array}{l}0.75 \\
0.75\end{array}$ & $\begin{array}{l}0.5 \\
0.25\end{array}$ & $\begin{array}{l}0.4 \\
0.1\end{array}$ & $\begin{array}{l}0.06 \\
0\end{array}$ & $\begin{array}{l}\mathbf{0} \\
\mathbf{0}\end{array}$ \\
\hline
\end{tabular}


TABLE III

BLOOD LEVELS IN RABBITS AFTER INTRAMUSCULAR INJECTION OF 20,000 UNITS OF PENICILLIN-OIL-BEESWAX (MILLED AND UNMILLED)

\begin{tabular}{|c|c|c|c|c|c|c|c|c|}
\hline \multirow{2}{*}{ Sample } & \multirow{2}{*}{$\begin{array}{c}\text { Rabbit } \\
\text { no. }\end{array}$} & \multicolumn{7}{|c|}{ Hours after injection } \\
\hline & & 1 & 2 & 4 & 6 & 8 & 12 & 24 \\
\hline \multirow[t]{2}{*}{ PC $1 / 16$ (milled) } & $\begin{array}{l}25 \\
26 \\
27\end{array}$ & $\begin{array}{l}0.25 \\
0.5 \\
0.25\end{array}$ & $\begin{array}{l}1.0 \\
1.5 \\
1.0\end{array}$ & $\begin{array}{l}2.0 \\
0.5 \\
1.0\end{array}$ & $\begin{array}{l}0.5 \\
0.5 \\
0.25\end{array}$ & $\begin{array}{l}0.5 \\
0.25 \\
0.125\end{array}$ & $\begin{array}{l}0.03 \\
\text { Nil } \\
\text { Nil }\end{array}$ & $\begin{array}{l}\text { Nil } \\
\text { Nil } \\
\text { Nil }\end{array}$ \\
\hline & Mean & 0.33 & 1.16 & 1.16 & 0.42 & 0.3 & 0.01 & Nil \\
\hline \multirow[t]{2}{*}{ PC $2 / 31$ (unmilled) } & $\begin{array}{l}28 \\
29 \\
30\end{array}$ & $\begin{array}{l}0.5 \\
0.125 \\
0.125\end{array}$ & $\begin{array}{l}0.5 \\
0.5 \\
1.0\end{array}$ & $\begin{array}{l}0.25 \\
0.125 \\
0.5\end{array}$ & $\begin{array}{l}0.7 \\
0.5 \\
0.5\end{array}$ & $\begin{array}{l}0.25 \\
0.25 \\
0.4\end{array}$ & $\begin{array}{l}0.125 \\
0.5 \\
0.5\end{array}$ & $\begin{array}{c}\text { Nil } \\
0.03 \\
\text { Nil }\end{array}$ \\
\hline & Mean & 0.25 & 0.67 & 0.3 & 0.57 & 0.3 & 0.375 & 0.01 \\
\hline
\end{tabular}

administer. It is possible to achieve fluidity at body temperature either by reducing the amount of beeswax from the original 4.5 per cent to 1 per cent or by submitting the suspension to a special milling process. The first alternative results in a marked drop in the time of circulation of penicillin in the blood ; the second method results in a partial reduction of the circulation time. For the milled preparation it is still essential to add 4.5 per cent of beeswax to the oil suspension ; otherwise the period of penicillin circulation in the blood drops. In our experiments we have observed that suspensions containing crystalline sodium penicillin or amorphous calcium penicillin give similar blood levels. Further, we have so far been unable to detect any effect of particle size of amorphous calcium penicillin, when administered as P.O.B., on blood levels, and a slight improvement in one experiment with crystalline sodium penicillin is of doubtful significance.

In using the milled penicillin beeswax suspension we make a compromise - to achieve an increased fluidity of the product we sacrifice to some extent the prolonged period of blood levels following injection of a solid penicillin suspension. The results of our tests confirm our earlier finding of an inverse relation between the fluidity of penicillin suspensions and the time during which the penicillin circulates in the blood.

One additional point should be emphasized when comparing the blood levels of penicillin after injections of solid and milled P.O.B. The solid suspension usually gives blood levels up to a period of about eighteen hours, whereas the milled P.O.B maintains blood levels over a shorter period, though the initial levels in the first one to three hours are higher than after injection of the solid P.O.B. This initial higher blood level (Table III and Figure) compensates for the reduced penicillin circulation in the blood and makes the milled suspension second only in value to aqueous solutions when higher bactericidal blood levels are required-blood levels essential to suppress microorganisms less susceptible to penicillin, such as occasionally occur in cases of septicaemia or chronic localized infections.

\section{Summary}

1. The effect of penicillin in oil-beeswax suspension depends on the consistency of the materia

TABLE IV

BLOOD LEVELS IN PATIENTS INJECTED WITH 1 ML. OF MILLED PENICILLIN SUSPENSION 300,000 UNITS PER ML.

\begin{tabular}{c|c|c|c|c|c|c|c|c|c|c|c}
\hline \multirow{3}{*}{ Patient } & \multicolumn{10}{c}{ Hours after injection } \\
\cline { 2 - 10 } & 1 & 2 & 3 & 4 & 5 & 6 & 11 & 15 & 16 & 18 & 20 \\
\hline 1 & 0.25 & 0.25 & 0.25 & 0.125 & 0.125 & 0.1 & 0.06 & 0.06 & 0.06 & 0.03 & Nil \\
2 & 2 & 1 & 1 & 0.5 & 0.5 & -0.2 & 0.06 & 3 Not tested further & \\
3 & 2 & 2 & 1 & 1 & 1.5 & 0.2 & - & & \\
\hline
\end{tabular}


and the amount of penicillin present. Amorphous calcium penicillin and crystalline sodium penicillin give equally effective products.

2. The amount of beeswax is one of the essential factors in delaying the absorption of penicillin.

3. The "milled" penicillin beeswax suspension is characterized by its ease of administration and gives blood levels midway between those following injections of the solid penicillin-oil-beeswax or of aqueous solutions of penicillin.

\section{REFERENCES}

Romansky, M. J., and Rittman, G. E. (1944). Science, 100, 196.

Ungar, J. (1946). Quart. J. Pharm. Pharmacol., 19, 544.

\begin{abstract}
Addendum
At the time of reading the proof of this communication, which had been reported at the January, 1948, meeting of the Association of Clinical Pathologists, I came across a paper by Dowling and others on "liquid" versus "solid" penicillin in oil and wax (J. Amer. med. Ass., 135, 567). This report gave the results of treatment of patients with fluid beeswax suspension. Their investigation seems to indicate that fluid suspensions may have similar absorbtiondelaying effect as solid suspensions if the former are prepared from penicillin particles of $50 \mu$ size or larger.
\end{abstract}

